\title{
Keefektifan Model Pembelajaran Scramble dengan Permainan Teka- Teki Silang terhadap Pemahaman Cerita Rakyat
}

\author{
Nur Adha Praba Hana Puri \\ Universitas PGRI Semarang \\ hanapuri.na@gmail.com \\ Dwi Prasetiyawati Diyah Hariyanti \\ Universitas PGRI Semarang \\ dwiprasetiyawati@gmail.com \\ Mira Azizah \\ Universitas PGRI Semarang \\ mira.azizah@gmail.com
}

\begin{abstract}
The background that drives this research is the low understanding of students about folklore. This is due to learning that only uses lectures and discussions so learning becomes less innovative. Based on this, the scramble learning model with crossword puzzles can be used as an alternative to innovative and fun learning. The purpose of this study is to find out and analyze the effectiveness of the scramble learning model with crossword games on understanding fourth grade folklore in elementary school. This research uses quantitative methods in the form of quasi experimental design with nonequivalent control group design. The problem in this study is the low understanding of students about folklore. The data of this study were obtained through questionnaires, observations, and interviews. This research was conducted in class IV at $S D \quad N$ TlogosariWetan 01 Semarang. This study produced $t_{\text {table }}=6.5016$ and the coefficient was significant at the level of $5 \%$ and $d k=70$, then obtained $t_{\text {table }}=1.99394$ so the value of $t_{\text {count }}>t_{\text {table }}$ and increase in the average learning outcomes from the control class posttest of 61.25 with results the experimental class posttest was 82,083. The completeness of classical learning in the experimental class shows $94.44 \%$ of students who complete with a total of 34 out of 36 students. So that it can be said as a scramble learning model with an effective crossword game on understanding the fourth grade folklore.
\end{abstract}

Keywords: Scramble Learning Model, Cross Puzzle Game, Understanding Folk Stories 


\begin{abstract}
Abstrak
Latar belakang yang mendorong penelitian ini adalah rendahnya pemahaman siswa tentang cerita rakyat. Ini karena pembelajaran yang hanya menggunakan ceramah dan diskusi sehingga pembelajaran menjadi kurang inovatif. Berdasarkan hal ini, model pembelajaran scramble dengan teka-teki silang dapat digunakan sebagai alternatif untuk pembelajaran yang inovatif dan menyenangkan. Tujuan dari penelitian ini adalah untuk mengetahui dan menganalisis efektivitas model pembelajaran scramble dengan permainan silang pada pemahaman cerita rakyat kelas empat di sekolah dasar. Penelitian ini menggunakan metode kuantitatif dalam bentuk quasi eksperimental design dengan nonequivalent control group design. Masalah dalam penelitian ini adalah rendahnya pemahaman siswa tentang cerita rakyat. Data penelitian ini diperoleh melalui kuesioner, observasi, dan wawancara. Penelitian ini dilakukan di kelas IV di SD N TlogosariWetan 01 Semarang. Penelitian ini menghasilkan t_table $=6.5016$ dan koefisiennya signifikan pada level $5 \%$ dan $\mathrm{dk}=70$, kemudian diperoleh t_table $=1.99394$ sehingga nilai t_count $>\mathrm{t}$ _table dan peningkatan hasil belajar rata-rata dari kelas kontrol posttest 61.25 dengan hasil posttest kelas eksperimen adalah 82.083. Ketuntasan pembelajaran klasikal di kelas eksperimen menunjukkan $94,44 \%$ siswa yang tuntas dengan total 34 dari 36 siswa. Sehingga bisa dikatakan sebagai model pembelajaran scramble dengan permainan teka-teki silang yang efektif untuk memahami cerita rakyat kelas empat.
\end{abstract}

Kata kunci: Model Pembelajaran Scramble, Game Cross Puzzle, Memahami Cerita Rakyat

\title{
Pendahuluan
}

Pembelajaran Bahasa Indonesia penting bagi peserta didik sekolah dasar, dengan adanya pembelajaran Bahasa Indonesia maka peserta didik bisa berkomunikasi dengan baik, mampu mengembangkan keterampilan berbahasa yang meliputi menyimak, berbicara, membaca, dan menulis. Muatan Bahasa Indonesia digunakan sebagai sarana untuk mengembangkan kemampuan dan keterampilan menalar pada kurikulum 2013. Menurut Tarigan (2009: 41) pengajaran bahasa bertujuan agar para pembelajar atau para siswa mempunyai keterampilan berbahasa. Terampil berbahasa seperti terampil menyimak, terampil berbicara, terampil membaca, dan terampil menulis.

Menurut Rahmat dalam (Sumira, 2018: 63) mengatakan bahwa Mata pelajaran Bahasa Indonesia sekolah dasar menuntut para peserta didik untuk dapat memahami konteks bacaan, sumber bacaan, kemampuan untuk berliterasi, kemampuan untuk menulis dan kemampuan dalam berbicara sesuai dengan kaidah dan ejaan yang tepat. Pembelajaran Bahasa Indonesia menurut Nafi'ah (2018: 32) diarahkan untuk meningkatkan kemampuan peserta didik dalam berkomunikasi menggunakan Bahasa Indonesia dengan baik dan benar, baik secara lisan maupun tulis serta menumbuhkan apresiasi terhadap karya sastra manusia Indonesia. Teks merupakan meteri utama pada kurikulum 2013. Beragam jenis teks dipelajari dalam kurikulum 2013. Namun, ditemukan permasalahan di sekolah dasar seperti peserta didik merasa jenuh dan bosan dengan pembelajaran Bahasa Indonesia dimana banyak teks bacaan yang disajikan. Sebagian besar peserta didik masih kurang lancar dalam membaca dan memahami isi bacaan. 
Sumira (2018: 63) mengatakan bahwa Bahasa Indonesia merupakan salah satu mata pelajaran yang dianggap kurang menarik oleh kalangan peserta didik sekolah dasar. Sebagian diantara peserta didik sekolah dasar tidak menyukai mata pelajaran Bahasa Indonesia dikarenakan faktor strategi pembelajaran yang dilakukan guru kurang inovatif. Strategi yang inovatif dan kontrstuktif akan mampu memberikan wawasan pengetahuan peserta didik serta meningkatkan aktivitas dan kreativitas peserta didik dalam proses pembelajaran.

Permasalahan tersebut juga ditemukan di kelas 4 SD N Tlogosari Wetan 01 Semarang berdasarkan wawancara dengan Guru Kelas IVB Ibu Nidia menyatakan bahwa, adanya tuntutan kurikulum 2013 guru lebih mementingkan mengejar materi daripada memberikan pembelajaran yang bervariasi bagi peserta didik. Muatan Bahasa Indonesia yang memiliki banyak bacaan membuat peserta didik merasa jenuh sehingga banyak peserta didik tidak memperhatikan pembelajaran. Akhirnya, peserta didik tidak bisa memahami isi atau makna dari sebuah bacaan dengan baik. Pembelajaran yang hanya menggunakan ceramah dan diskusi membuat pembelajaran menjadi monoton. Belum adanya variasi pembelajaran seperti penggunaan model, metode dan media yang inovatif mengakibatkan pembelajaran menjadi membosankan, sehingga peserta didik banyak yang tidak memperhatikan guru dan lebih aktif bermain sendiri. Sedangkan menurut Ibu Dwi Guru Kelas IVA menyatakan bahwa dalam pembelajaran Bahasa Indonesia lebih dari 50\% peserta didik kurang berminat dalam hal membaca, peserta didik merasa bosan ketika diminta untuk membaca sebuah teks bacaan. Akhirnya peserta didik kesulitan dalam memahami sebuah isi atau makna dari bacaan.

Hasil observasi di kelas IVA, 40\% dari 38 peserta didik tidak memperhatikan guru dan bercerita dengan temannya. Guru mengajar hanya menggunakan buku siswa ketika pembelajaran pada muatan Bahasa Indonesia dilaksanakan. Sedangkan untuk model dan metode yang inovatif belum diterapkan di dalam kelas. Jika melihat dari nilai UAS muatan Bahasa Indonesia rata-rata nilai kelasnya masih dibawah KKM yaitu 62,5 sedangkan KKM yang telah ditentukan adalah 75 . Peserta didik yang mendapat nilai di bawah KKM ada 34 peserta didik dan yang mendapat nilai di atas KKM ada 6 peserta didik.

Kondisi di atas perlu mendapat perhatian mengingat pentingnya keterampilan berbahasa untuk dapat berkomunikasi dengan baik. Namun, guru perlu menerapkan adanya variasi pembelajaran salah satunya dengan menggunakan model yang inovatif, agar peserta didik mampu memahami isi dan makna dari sebuah bacaan. Salah satu model yang dapat digunakan adalah model pembelajaran scramble.

Scramble merupakan model pembelajaran dalam bentuk permainan acak kata, kalimat, atau paragraph yang dilakukan secara berkelompok dan memiliki tujuan untuk dapat membantu peserta didik menemukan jawaban dan menyelesaikan permasalahan yang ada dalam pembelajaran Bahasa Indonesia agar peserta didik menjadi aktif, kreatif, berfikir kritis dalam menyelesaikan soal dan mampu bekerja sama dalam kelompok (Shoimin, 2014: 166).

Penggunaan model pembelajaran scramble akan lebih bagus dan bervariasi apabila menambahkan suatu permainan. Pembelajaran yang dikemas dengan menggunakan suatu model disertai dengan permaianan akan membuat peserta didik menjadi lebih aktif dan senang mengikuti kegiatan pembelajaran. Teka-teki silang adalah permainan yang bisa digunakan bersama model pembelajaran scramble.

Teka-teki silang menurut Cahyo (2011: 63) merupakan kegiatan mengingat, mencari, dan mencocokan kata yang pas tidak hanya sesuai dengan jawabannya, tetapi juga jumlah kotak yang disediakan, teka-teki silang merupakan suatu permainan kata, yang dapat digunakan dalam membantu pembelajaran bahasa agar pembelajaran 
lebih menarik dan berkesan bagi peserta didik". Hal ini juga disampaikan Triharso (2013: 1), "Bermain adalah suatu kegiatan yang dilakukan dengan atau tanpa mempergunakan alat, yang menghasilkan pengertian dan memberikan informasi, memberikan kesenangan maupun mengembangkan imajinasi anak".

Jadi pembelajaran menggunakan model pembelajaran scramble dengan permainan teka-teki silang dapat mempermudah peserta didik dalam menerima pelajaran. $\mathrm{Hal}$ ini didukung penelitian Putra (2014), bahwa terdapat perbedaan yang signifikan hasil belajar Bahasa Indonesia antara kelompok yang dibelajarkan dengan model pembelajaran scramble berbantu media permainan teka-teki silang dan kelompok yang dibelajarkan dengan model konvensional pada peserta didik kelas VA dan VB di SD Negeri 1 Sangsit.

Berdasarkan permasalahan di atas maka peneliti menerapkan alternatif pembelajaran yang lebih menarik dengan menggunakan model pembelajaran scramble dengan permaianan teka-teki silang terhadap pemahaman cerita rakyat kelas IV Sekolah Dasar.

Rumusan masalah yang diperoleh dari latar belakang di atas yaitu: "bagaimanakah keefektifan model pembelajaran scramble dengan permainan teka-teki silang terhadap pemahaman cerita rakyat kelas IV SD N Tlogosari Wetan 01 Semarang?"

Tujuan dalam penelitian ini adalah untuk mengetahui dan menganalisis keefektifan model pembelajaran scramble dengan permaianan teka-teki silang terhadap pemahaman cerita rakyat peserta didik kelas IV SD N Tlogosari Wetan 01 Semarang.

\section{Metode}

Penelitian ini menggunakan metode penelitian eksperimen dan menggunakan metode kuantitatif untuk pengolahan datanya. Metode penelitian eksperimen dapat diartikan sebagai metode penelitian yang digunakan untuk mencari pengaruh perlakuan tertentu terhadap yang lain dalam kondisi yang terkendalikan, Sugiyono (2017: 107). Metode eksperimen mengkaji hubungan dua variabel atau lebih. Pada eksperimen peneliti harus melakukan manipulasi atau perlakuan terhadap variabel bebas, melakukan pengukuran sendiri terhadap variabel bebas dan terikat (Sudjana, 2013: 56).

Desain penelitian yang digunakan peneliti adalah Quasi Experimental Design. Bentuk desain eksperimen ini merupakan pengembangan dari true eksperimental design. Desain ini mempunyai kelompok kontrol, tetapi tidak dapat berfungsi sepenuhnya untuk mengontrol variabel-variabel luar yang mempengaruhi pelaksanaan eksperimen, Sugiyono (2017: 114). Bentuk desain yang digunakan adalah Nonequivalent Control Group Design. Dalam desain ini terdapat dua kelompok yaitu kelompok eksperimen dan kelompok kontrol yang tidak dipilih secara random, Sugiyono (2017: 116).

Dua kelompok tersebut kemudian diberi pretest untuk mengetahui keadan awal adakah perbedaan antara kelompok eksperimen dan kelompok kontrol. Hasil pretest yang baik bila nilai kelompok eksperimen tidak berbeda secara signifikan. Pengaruh perlakuan adalah $\left(O_{2}-O_{1}\right)\left(O_{4}-O_{3}\right)$. Setelah pemberian pretest, selanjutnya pada kelas eksperimen akan diberi perlakuan yaitu menggunakan model pembelajaran scramble dengan permainan teka-teki silang dan kelas kontrol menggunakan metode konvensional. Kemudian pada kelas eksperimen dan kelas kontrol akan diberikan postest. Pengaruh ada atau tidaknya perbedaan kelas eksperimen dan kelas kontrol setelah diberikan perlakuan akan diketahui dengan melakukan analisis uji beda statistik t-test, Sugiyono (2017: 112). 
Partisipan pada penelitian ini adalah peserta didik kelas IV SD N Tlogosari Wetan 01, peserta didik kelas IVA dengan jumlah 36 dan peserta didik kelas IVB dengan jumlah 36 SD N Tlogosari Wetan 01 Semarang Tahun Ajaran 2018/2019. Jadi, jumlah sampel dalam penelitian ini adalah 72 peserta didik.

Instrumendalam penelitian ini adalah tes yang diberikan kepada peserta didik yang digunakan untuk mengetahui tingkat pemahaman peserta didik. Sebelum melaksanakan penelitian maka tes diuji coba terlebih dahulu dan dianalisis validitas, reliabilitas, taraf kesukaran dan daya pembeda. Setelah soal valid maka soal dapat digunakan untuk penelitian.

Dalam penelitian ini, menggunakan teknik pengumpulan data berupa sebagai berikut : 1) Observasi dilakukan pengamatan didalam kelas pada saat proses pembelajaran berlangsung. Pengamatan yang dilakukan berupa pengamatan pengajaran yang dilakukan guru serta respon atau tanggapan peserta didik terhadap pembelajaran yang dilakukan. 2) Wawancara yang digunakan peneliti adalah wawancara terstruktur. Wawancara dilakukan peneliti dengan tanya jawab kepada guru kelas IVA dan IVB SD N Tlogosari Wetan 01 Semarang 3) Angket yang diberikan kepada peserta didik untuk mengetahui permasalahan yang dihadapi peserta didik saat proses pembelajaran berlangsung.

Dalam penelitian ini menggunakan teknik analisis data sebagai berikut :1) Analisi data awal menggunakan uji normalitas dan uji homogenitas 2) Analisis data akhir menggunakan uji normalitas, uji homogenitas, uji hipotesisi dan uji ketuntasan belajar.

\section{Hasil}

Berdasarkan hasil penelitian yang telah dilaksanakan oleh peneliti, data hasil pretest kelas IVA menggunakan model scramble dengan permainan teka-teki silang dan kelas IVB menggunakan metode konvensioal atau ceramah dengan jumlah 72 peserta didik yang masing-masing kelas terdiri dari 36 peserta didik kelas IVA dan 36 peserta didik kelas IVB pada Tema 8 Lingkungan Tempat Tinggalku Subetema 1 Pembelajaran 1-3. Berikut rekapitulasi nilai pretest peserta didik kelas eksperimen dan kelas kontrol:

Tabel 1. Rekapitulasi Nilai Pretest Peserta Didik

\begin{tabular}{l|c|c}
\hline & Kelas Kontrol & Kelas Eksperimen \\
\hline Jumlah Skor & 2005 & 2215 \\
\hline Nilai Terendah & 25 & 25 \\
\hline Nilai Tertinggi & 80 & 90 \\
\hline Jumlah Peserta Didik & 36 & 36 \\
\hline Rata-Rata & 55,694 & 61,528 \\
\hline
\end{tabular}

Berdasarkan tabel 1 dengan jumlah peserta didik 36 di kelas eksperimen dan 36 peserta didik di kelas kontrol diperoleh jumlah hasi nilai pretest di kelas eksperimen 2215 dan jumlah hasil nilai kelas kontrol 2005. Perhitungan rata-rata di kelas eksperimen adalah 61,523 sedangkan rata-rata nilai pretest di kelas kontrol adalah 55,694 .

\section{Uji Normalitas Data Awal Kelas Eksperimen dan Kelas Kontrol}

Berdasarkan uji normalitas kelas eksperimen diperoleh $\mathrm{L}_{\mathrm{o}}=0,084$ dengan $\mathrm{n}=36$ dan taraf nyata $a=0,05$ dari daftar tabel liliefors didapat $\mathrm{L}_{\text {tabel }}=0,1477$. Berdasarkan perhitungan tersebut $\mathrm{L}_{0}<\mathrm{L}_{\text {tabel }}$ atau $0,084<0,1477$ sehinggan $\mathrm{H}_{0}$ diterima. Sedangkan kelas kontrol diperoleh $\mathrm{L}_{o}=0,0953$ dengan $\mathrm{n}=36$ dan taraf nyata $\alpha=$ 0,05 dari tabel liliefors didapat $\mathrm{L}_{\text {tabel }}=0,1477$ dari perhitungan tersebut 
$\mathrm{L}_{\mathrm{o}}<\mathrm{L}_{\text {tabel }}$ atau $0,095<0,1477$. Dari hasil penelitian tersebut dinyatakan bahwa sampel kelas eksperimen berasal dari populasi yang berdistribusi normal.

\section{Uji Normalitas Data Akhir Kelas Eksperimen dan Kelas Kontrol}

Berdasarkan uji normalitas kelas eksperimen diperoleh $\mathrm{L}_{\mathrm{o}}=0,1388$ dengan $\quad \mathrm{n}=36$ dan taraf nyata $\alpha=0,05$ dari daftar tabel liliefors didapat $\mathrm{L}_{\text {tabel }}=0,1477$. Berdasarkan perhitungan tersebut $\mathrm{L}_{0}<\mathrm{L}_{\text {tabel }}$ atau $0,1388<0,1477$ sehinggan $\mathrm{H}_{0}$ diterima. Sedangkan kelas kontrol diperoleh $\mathrm{L}_{\mathrm{o}}=0,0993$ dengan $\mathrm{n}=36$ dan taraf nyata $\alpha=0,05$ dari tabel liliefors didapat $\mathrm{L}_{\text {tabel }}=0,1477$ dari perhitungan tersebut $\mathrm{L}_{0}<\mathrm{L}_{\text {tabel }}$ atau $0,0993<0,1477$. Dari hasil penelitian tersebut dinyatakan bahwa sampel kelas eksperimen berasal dari populasi yang berdistribusi normal.

\section{Uji Homogenitas Awal Nilai Pretest Kelas Eksperimen dan Kelas Kontrol}

Berdasarkan uji homogenitas dari data nilai pretest kelas eksperimen dan kelas kontrol, maka diperoleh $F_{\text {hitung }}=1,1416$ dari daftar tabel diperoleh nilai $F_{\text {tabel }}=1,76$ dan taraf signifikan 5\%. Dari perhitungan tersebut didapat bahwa $F_{\text {hitung }}<F_{\text {tabel }}$ sehingga $\mathrm{H}_{0}$ diterima. Kesimpulan yang diperoleh dari uji homogenitas awal pada nilai pretest kelas eksperimen dan kelas kontrol adalah bahwa kedua kelompok tersebut memiliki varians yang sama.

\section{Uji Homogenitas Akhir Nilai Posttest Kelas Eksperimen dan Kelas Kontrol}

Berdasarkan uji homogenitas dari data nilai posttest kelas eksperimen dan kelas kontrol, diperoleh $F_{\text {hitung }}=1,6522$ dari daftar tabel diperoleh nilai $F_{\text {tabel }}=1,76$ dan taraf signifikan 5\%. Dari perhitungan tersebut didapat bahwa $F_{\text {hitung }}<F_{\text {tabel }}$ sehingga $\mathrm{H}_{0}$ diterima. Kesimpulan yang diperoleh dari uji homogenitas awal pada nilai posttest kelas eksperimen dan kelas kontrol adalah bahwa kedua kelompok tersebut memiliki varians yang sama.

\section{Uji hipotesis menggunakan uji-t}

Berdasarkan perhitungan data dari kelas eksperimen dan kelas kontrol mendapatkan hasil bahwa kedua data tersebut berdistribusi normal dan homogen Hasil pengujian dapat dilihat dari tabel 4.3 sebagai berikut:

Tabel 2. Pengujian Uji-t Kelas Eksperimen dan Kelas Kontrol

\begin{tabular}{c|c|c}
\hline Kelas & Eksperimen & Kontrol \\
\hline $\mathrm{N}$ & 36 & 36 \\
\hline Varians $\left(S^{2}\right)$ & 99,1071 & 270,536 \\
\hline$t_{\text {hitung }}$ & \multicolumn{2}{|c}{1,9901694} \\
\hline$t_{\text {tabel }}$ & \multicolumn{2}{|c}{} \\
\hline
\end{tabular}

Berdasarkan tabel 1.2 di peroleh varians $\left(\mathrm{s}^{2}\right)$ pada kelas eksperimen 99,1071 sedangkan pada kelas kontrol 270,536. Berdasarkan uji-t tersebut, di peroleh $\mathrm{t}_{\text {hitung }}$ 6,5016 dan $\mathrm{t}_{\text {tabel }} 1,99394$ dengan $\mathrm{dk} \mathrm{n}_{1}+\mathrm{n}_{2}-2=36+36-2=70, \alpha=5 \%$. Dari perhitungan diperoleh $t_{\text {hitung }}>t_{\text {tabel }} l=6,5016>1,99394$ sehingga $\mathrm{H}_{0}$ ditolak, artinya model pembelajaran scramble dengan permainan teka-teki silang efektif terhadap pemahaman cerita rakyat siswa kelas IV SD N Tlogosari Wetan 01 Semarang.

\section{Uji ketuntasan belajar}

Jika persentase ketuntasan individu $\geq 75 \%$ maka tuntas dan jika persentase individu $<75 \%$ maka tidak tuntas. Pada kelas eksperimen jumlah peserta didik 34 tuntas 
dengan nilai $>75$ dan 2 peserta didik tidak tuntas mendapat nilai $<75$. Sedangkan pada kelas kontrol jumlah peserta didik 13 tuntas dengan nilai $>75$ dan 23 peserta didik tidak tuntas mendapat nilai $<75$. Ketuntasan belajar individu pada kelas eksperimen dan kelas kontrol dapat dilihat pada gambar berikut:

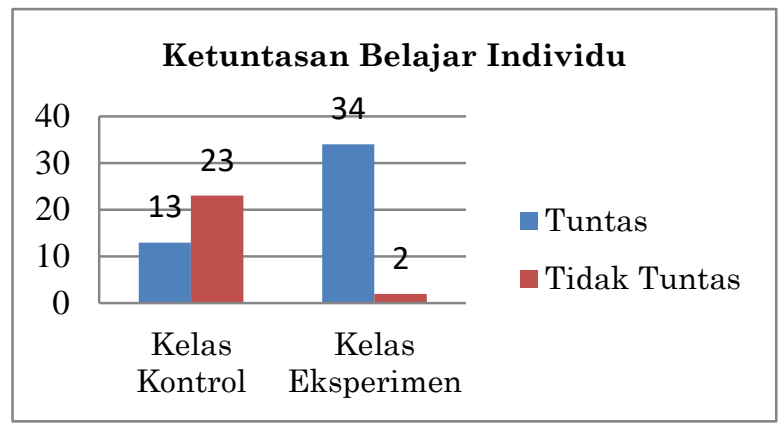

Gambar 1. Diagram Ketuntasan Belajar Individu

Jika persentase ketuntasan belajar klasikal $\geq 60 \%$ maka tuntas dan jika persentase ketuntasan belajar klasikal $<60 \%$ maka tidak tuntas. Ketuntasan klasikal kelas eksperimen mencapai 94,44\% sedangkan pada kelas kontrol mencapai 36,11\%. Suatu kelas dinyatakan tuntas secara klasikal apabila mencapai $60 \%$, pada kelas eksperimen ketuntasan belajar klasikal mencapai 94,44\% maka kelas eksperimen mencapai ketuntasan klasikal. Pada kelas kontrol ketuntasan belajar klasikal mencapai $36,11 \%$ maka pada kelas kontrol belum mencapai ketuntasan belajar klasikal. Ketuntasan belajar klasikal kelas eksperimen dan kelas kontrol dapat dilihat pada tabel 1 dan 2 berikut.

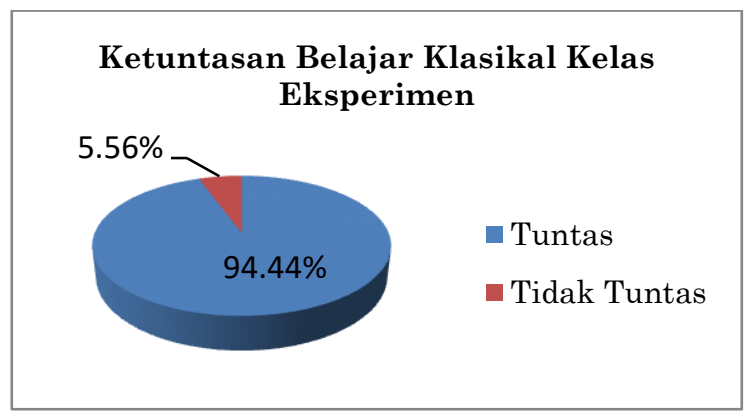

Gambar 2. Diagram Ketuntasan Belajar Klasikal Kelas Eksperimen

Berdasarkan Gambar 1.4, ketuntasan belajar klasikal kelas eksperimen mencapai $94,44 \%$ dan 5,56\% peserta didik tidak tuntas. Dengan demikian, kelas eksperimen dapat dikatakan tuntas secara klasikal karena $>60 \%$ peserta didik tuntas belajar.

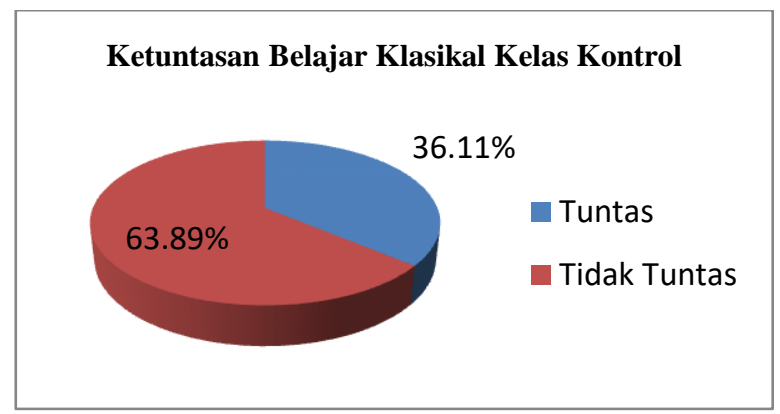

Gambar 3. Diagram Ketuntasan Belajar Klasikal Kelas Kontrol 
Berdasarkan Gambar 1.5 ketuntasan belajar klasikal kelas kontrol mencapai 36,11\% dan $63,89 \%$ peserta didik tidak tuntas. Dengan demikian, kelas kontrol dikatakan tidak tuntas secara klasikal karena $\leq 60 \%$ peserta didik tuntas belajar.

Berdasarkan penelitian terdahuku dari Astuti (2017) dengan judul "Pengaruh Model Pembelajaran Scramble Terhadap Hasil Belajar Bahasa Indonesia Peserta didik Kelas III Kecamatan Buleleng" Berdasarkan hasil penelitian dan pembahasan, terdapat perbedaan hasil belajar Bahasa Indonesia yang signifikan antara kelompok peserta didik yang dibelajarkan melalui model pembelajaran scramble berbantuan kartu pertanyaan dengan kelompok peserta didik yang dibelajarkan melalui model pembelajaran konvensional di kelas III Gugus I Kecamatan Buleleng Kabupaten Buleleng Tahun Pelajaran 2016/2017. Hasil tersebut diperoleh dari perhitungan uji$\mathrm{t}$, t_hitung $=11,55>\mathrm{t}$ _tabel $=1,671$ (dengan db 72 dan taraf signifikansi $5 \%$ ), sehingga $\mathrm{H} \_0$ ditolak dan $\mathrm{H} \_1$ diterima. Dengan demikian dapat dinyatakan bahwa model pembelajaran scramble berbantuan kartu pertanyaan berpengaruh signifikan terhadap hasil belajar Bahasa Indonesia peserta didik kelas III di Gugus I Kecamatan Buleleng.

\section{Pembahasan}

Hasil penelitian menunjukan bahwa kelas yang menggunakan model pembelajaran scramble dengan permainan teka-teki silang, kelas menjadi aktif dan peserta didik terlihat sangat antusias mengikuti pembelajaran. Kelas ini dibuat menjadi kelompok-kelompok kecil di dalam kelas agar peserta didik dapat berdiskusi dengan kelompoknya untuk memecahkan soal dengan menggunakan media kartu pertanyaan dan permainan teka-teki silang. Hasil penelitian pada kelas eksperimen yang diberi perlakuan dengan menggunakan model scramble dan permainan tekateki silang memiliki tingkat pemahaman terhadap cerita rakyat lebih tinggi daripada kelas yang menggunakan metode ceramah. Dilihat dari skor rata-rata kondisi akhir kelas eksperimen yaitu sebesar 82,08 dan skor kelas kontrol sebesar 61,25 . Hal ini berarti bahwa setiap indikator pada soal yang diberikan kepada peserta didik pada kelas eksperimen lebih banyak yang tercapai dibandingkan dengan kelas kontrol. Berbeda dengan kelas kontrol, secara keseluruhan metode mengajar dengan ceramah pada tema 8 Lingkungan Tempat Tinggalku di kelas kontrol berjalan dengan baik. Namun, peserta didik kurang antusias dalam proses pembelajaran, lebih dari $50 \%$ peserta didik masih bermain dengan temannya dan tidak memperhatikan guru.

Sesuai dengan penelitian desain yang digunakan adalah Quasi Experimental Design.Desain ini mempunyai kelompok kontrol, tetapi tidak dapat berfungsi sepenuhnya untuk mengontrol variabel-variabel luar yang mempengaruhi pelaksanaan eksperimen, Sugiyono (2017: 114).Bentuk desain yang digunakan adalah Nonequivalent Control Group Design. Dalam desain ini terdapat dua kelompok yaitu kelompok eksperimen dan kelompok kontrol yang tidak dipilih secara random, Sugiyono (2017: 116). Pretest digunakan untuk mengetahui keadan awal adakah perbedaan antara kelompok eksperimen dan kelompok kontrol. Setelah pemberian pretest, selanjutnya pada kelas eksperimen akan diberi perlakuan yaitu menggunakan model scramble dengan permainan teka-teki silang dan kelas kontrol menggunakan metode konvensional. Kemudian pada kelas eksperimen dan kelas kontrol akan diberikan postest.

Pada penelitian ini dilakukan uji persyaratan yang dilakukan setelah diberi tes hasil belajar pada kedua kelompok sampel maka diperoleh data awal dan data akhir yang selanjutnya dilakukan analisis data. Nilai pretest digunakan untuk menganalisis data awal dan nilai posttest digunakan untuk menganalisis data akhir. Data hasil 
belajar pretest harus dilakukan uji persyaratan analisis data, yaitu dengan uji normalitas awal dan uji homogenitas awal.

Uji normalitas awal dilakukan untuk mengetahui data yang diperoleh berasal dari populasi yang berdistribusi normal atau tidak. Uji normalitas awal digunakan dengan menggunakan uji liliefors, dengan jumlah $n=36$ dengan taraf nyata $\alpha=0,05$ maka diperoleh $L_{\text {tabel }}=0,1477$ dan $L_{0}=0,084$ pada kelas eksperimen sedangkan pada kelas kontrol dengan jumlah $n=36$ dengan taraf nyata $\alpha=0,05$ maka diperoleh $L_{\text {tabel }}=0,1477$ dan $L_{0}=0,0953$ nilai pretest dikatakan berdistribusi normal apabila $L_{0}<L_{\text {tabel. }}$. Berdasarkan nilai pretest pada kelas eksperimen dan kelas kontrol $L_{0}<L_{\text {tabel }}$ dengan demikian hipotesis atau $H_{0}$ diterima, sehingga dapat disimpulkan bahwa nilai pretest pada kelas kontrol dan kelas eksperimen berasal dari populasi yang berdistribusi normal.

Nilai pretest yang berdistribusi normal selanjutnya dilakukan uji homogenitas dengan jumlah $n=36$ dengan taraf signifikan $\alpha=5 \%$ maka diperoleh nilai $F=$ 1,1416 dan $F_{\text {tabel }}=1,76$. Data memiliki varian yang sam apabila $F_{\text {hitung }}<F_{\text {tabel }}$. Setelah dilakukan perhitungan $F_{\text {hitung }}<F_{\text {tabel }}$ yaitu $1,1416<1,76$ maka dapat disimpulkan bahwa data pretest berasal dari populasi yang memiliki varian yang sama atau homogen.

Uji pesyaratan akhir dengan menggunakan uji normalitas akhir dan uji homogenitas akhir menggunakan nilai posttest. Uji normalitas akhir dengan jumlah $n=36$ dengan taraf nyata $\alpha=0,05$ maka diperoleh $L_{\text {tabel }}=0,1477$ dan $L_{0}=0,1388$ pada kelas eksperimen sedangkan pada kelas kontrol dengan jumlah $n=36$ dengan taraf nyata $\alpha=0,05$ maka diperoleh $L_{\text {tabel }}=0,1477$ dan $L_{0}=0,0993$. Nilai posttest dikatakan berdistribusi normal apabila $L_{0}<L_{\text {tabel. }}$. Dari perhitungan diperoleh $L_{0}<L_{\text {tabel }}$ dengan demikian hipotesis atau $H_{0}$ diterima, sehingga dapat disimpulkan bahwa nilai posttest pada kelas kontrol dan kelas eksperimen berasal dari populasi yang berdistribusi normal.

Selanjutnya dilakukan uji homogenitas akhir untuk mengetahui data nilai posttest berasal dari populasi yang memiliki varian yang sama atau tidak. Uji homogenitas dengan jumlah $n=36$ dengan taraf signifikan $\alpha=5 \%$ maka diperoleh nilai $F_{\text {hitung }}=$ 1,6522 dan $F_{\text {tabel }}=1,76$. Data memiliki varian yang sam apabila $F_{\text {hitung }}<F_{\text {tabel }}$. Setelah dilakukan perhitungan $F_{\text {hitung }}<F_{\text {tabel }}$ yaitu $1,6522<1,76$ maka dapat disimpulkan bahwa data posttest berasal dari populasi yang memiliki varian yang sama atau homogen.

Setelah melakukan uji persyaratan selanjutnya melakukan uji hipotesis yaitu dengan menggunakan uji-t untuk menguji keefektifan model scramble dengan permainan teka-teki silang terhadap pemahaman cerita rakyat kelas IV SD N Tlogosari Wetan 01 Semarang. Berdasarkan perhitungan diperoleh hasil $t_{\text {hitung }}=$ 6,5016 dan $t_{\text {tabel }}=1,99394$ dengan $d k=n_{1}+n_{2}-2=36+36-2=70$ dan taraf signifikan 5\%. Karena $t_{\text {hitung }}>t_{\text {tabel }}$ yaitu 6,5016 $>1,99394$ maka $H_{0}$ ditolak artinya model pembelajaran scramble dengan permainan teka-teki silang efektif terhadap pemahaman cerita rakyat siswa kelas IV SD N Tlogosari Wetan 01 Semarang.

Ketuntasan belajar klasikal pada kelas eksperimen mencapai 94,44\%, peserta didik yang tuntas belajar sejumlah 34 speserta didik dari 36 peserta didik. Sedangkan pada kelas kontrol ketuntasan belajar klasikal mencapai 36,11\%, peserta didik yang tuntas belajar sejumlah 13 dari 36 peserta didik. Berdasarkan hasil analisis tersebut, kelas eksperimen dapat dikatakan tuntas secara klasikal karena $>60 \%$ peserta didik tuntas belajar. Dengan demikian pembelajaran scramble dengan 
permainan teka-teki silang efektif terhadap pemahaman cerita rakyat siswa kelas IV SD N Tlogosari Wetan 01 Semarang.

Hasil belajar yang tinggi pada kelas eksperimen yang diberi perlakuan berupa model pembelajaran scramble dibanding kelas kontrol yang tidak diberi perlakuan atau pembelajaran dengan menggunakan metode konvensional atau ceramah disebabkan oleh keterlibatan aktif peserta didik dalam pembelajaran. Menggunakan model scramble dengan permainan teka-teki silang membuat peserta didik aktif dan senang saat pembelajaran berlangsung, peserta didik antusias mengikuti pembelajaran karena sebelumnya belum pernah menerima pembelajaran dengan permainan.

Pada pembelajaran konvensional, siswa lebih banyak mendengarkan penjelasan guru dikelas dan melaksanakan tugas jika guru memberikan latihan soal-soal kepada peserta didik. Kelemahan pembelajaran konvensional yaitu kegiatan pembelajaran hanya berusat pada guru, tugas guru adalah memberi pengetahuan dan tugas kepada peserta didik dan peserta didik hanya sebagai penerima pengetahuan yang pasif.

Setelah dilakukan uji normalitas awal, uji normalitas akhir, uji homogenitas awal, uji homogenitas akhir dan uji hipotesis dapat disimpulkan bahwa model pembelajaran scramble dengan permainan teka-teki silang efektif terhadap pemahaman cerita rakyat, dengan demikian tujuan penelitian telah tercapai.

Penelitian menggunakan model pembelajaran scramble dengan permainan teka-teki silang terhadap pemahaman cerita rakyat kelas IV SD N Tlogosari Wetan 01 Semarang merupakan pengembangan penelitian dari Astuti (2017) dengan judul "Pengaruh Model Pembelajaran Scramble Terhadap Hasil Belajar Bahasa Indonesia Peserta didik Kelas III Kecamatan Buleleng" Berdasarkan hasil penelitian dan pembahasan, terdapat perbedaan hasil belajar Bahasa Indonesia yang signifikan antara kelompok peserta didik yang dibelajarkan melalui model pembelajaran scramble berbantuan kartu pertanyaan dengan kelompok peserta didik yang dibelajarkan melalui model pembelajaran konvensional di kelas III Gugus I Kecamatan Buleleng Kabupaten Buleleng Tahun Pelajaran 2016/2017. Hasil tersebut diperoleh dari perhitungan uji-t, $t_{\text {hitung }}=11,55>t_{\text {tabel }}=1,671$ (dengan $\mathrm{db} 72$ dan taraf signifikansi $5 \%$ ), sehingga $H_{0}$ ditolak dan $H_{1}$ diterima. Dengan demikian dapat dinyatakan bahwa model pembelajaran scramble berbantuan kartu pertanyaan berpengaruh signifikan terhadap hasil belajar Bahasa Indonesia peserta didik kelas III di Gugus I Kecamatan Buleleng.

Hasil dari pengembangan diperoleh bahwa model pembelajaran scramble dengan permainan teka-teki silang berpengaruh signifikan terhadap pemahaman cerita rakyat kelas IV SD N Tlogosari Wetan 01 Semarang dengan hasil penelitian menggunakan uji t, yaitu $t_{\text {hitung }}=6,5016>t_{\text {tabel }}=1,99394$ artinya $H_{0}$ ditolak dan $H_{a}$ diterima yaitu pemahaman cerita rakyat pada kelas eksperimen lebih tinggi dari kelas kontrol, sehingga model pembelajaran scramble lebih efektif dari pada pemahaman cerita rakyat yang tidak menggunakan model pembelajaran scramble. Hal ini berarti bahwa model scramble dengan permainan teka-teki silang berpengaruh signifikan terhadap pemahaman cerita rakyat kelas IV SD N Tlogosari Wetan 01 Semarang. Sehingga penelitian ini saling melengkapi penelitian dari Astuti (2018) dengan ditambahnya permainan teka-teki silang di dalam penggunaan model pembelajaran scramble. 


\section{Simpulan}

Berdasarkan analisis data, hasil penelitian dan pembahasan, maka dapat disimpulkan bahwa model pembelajaran scramble dengan permainan teka-teki silang efektif terhadap pemahaman cerita rakyat kelas IV SD N Tlogosari Wetan 01 Semarang. Hal tersebut dapat ditunjukkan dengan adanya hasil perhitungan uji t, yaitu $t_{\text {hitung }}=6,5016>t_{\text {tabel }}=1,99394$ artinya $H_{0}$ ditolak dan $H_{a}$ diterima yaitu hasil pemahaman cerita rakyat pada kelas eksperimen lebih tinggi dari kelas kontrol, sehingga model pembelajaran scramble lebih efektif dari pada hasil pemahaman cerita rakyat yang tidak menggunakan model pembelajaran scramble. Nilai rata-rata kelas eksperimen 82,083 dan kelas kontrol dengan nila rata-rata 61,25. Dengan demikian, ada perbedaan rata-rata pemahaman cerita rakyat peserta didik kelas eksperimen dan peserta didik kelas kontrol.

\section{Saran}

Berdasarkan simpulan di atas, maka peneliti memberi saran antara lain sebagai berikut:Bagi guru, model pembelajaran scramble dapat dicoba dan diterapkan untuk pembelajaran lain. Dalam pembelajaran menggunakan model pembelajaran scramble, guru diharapkan mampu sebagai fasilitator, motivator, dan inovator dalam pembelajaran agar peserta didik mampu melaksanakna pembelajaran dengan baik dan aktif dalam mencari jawaban dari sumber-sumber lain sehingga peserta didik tidak selalu diberikan materi terus-menerus. Bagi peserta didik dalam mengikuti proses diskusi sebaiknya antar peserta didik bekerjasama dan saling menghargai pendapat antara satu dengan yang lain. Hal ini diharapkan agar peserta didik lebih memahami materi yang sedang mereka pelajari dan bisa berdiskusi dengan baik.Bagi peneliti, dalam penerapan model pembelajaran scramble dapat menggunakan media yang menarik dan inovatif, disesuaikan dengan materi yang diajarkan.

\section{Referensi}

Astuti, D.K. 2017. "Pengaruh Model Pembelajaran Scramble terhadap Hasil Belajar Bahasa Indonesia Siswa Kelas III Kecamatan Buleleng". E-Journal PGSD Universitas Pendidikan Ganesha Mimbar PGSD Vol: 5 No: 2.

Cahyo, N.A. 2011. Gudang Permainan Kreatif Khusus Asah Otak Kiri Anak. Jakarta: Rineka Cipta

Nafi'ah, S.A. 2018. Model-Model Pembelajaran Bahasa Indonesia di SD/MI. Yogyakarta: Ar-Ruzz Media.

Putra, P. A. 2014. "Pengaruh Model Scramble Berbantu Media Teka-Teki Silang Terhadap Hasil Belajar Bahasa Indonesia Siswa Kelas V SD Negeri Sangsit”. E-Journal PGSD Universitas Pendidikan Ganesha Mimbar PGSD Vol: 2 No: 1.

Shoimin, A. 2014. 68 Model Pembelajaran Inovatif dalam Kurikulum 2013.Yogyakarta: Ar-Ruzz Media.

Sudjana. 2013. Meode Statistika. Bandung: TarsitoSugiyono. 2017. Metodologi Penelitian. Bandung: Alfabeta.

Sugiyono. 2017. Metodologi Penelitian. Bandung: Alfabeta. 
Puri, N., A., H. Hariyanti, D., P., D. \& Azizah, M.

Sumira, D. Z. 2018. "Pengaruh Metode Scramble dan Minat Baca terhadap Kemampuan Membaca Pemahaman Siswa Sekolah Dasar". Indonesian Journal of Primary Education Vol: 2 No: 1 Tahun 2018.

Tarigan. G. H. 2009. Metodologi Pengajaran Bahasa. Bandung: Percetakan Angkasa.

Undang-Undang Republik Indonesia Nomor 20 Tahun 2000 tentang Sistem Pendidikan Nasional. 